\title{
MOTHER MARY IN THE RISING SUN: A "RITUAL DRAMA" AMONG THE CSANGO HUNGARIANS
}

\begin{abstract}
The paper deals with the origin and symbolism of the multirooted rite of "Looking into the Sun at Dawn," performed yearly on Pentecost, as a part of the Csíksomlyó indulgence (Şumuleu Ciuc, Romania) organised by the Catholic Church. Predominantly female ethnic Csango Hungarians performed this rite until the 21 st century, and in the course of their communal visions they often saw the shape of Virgin Mary in the rising sun. The local Franciscan church shelters a 16th century Mother Mary statue - to which miraculous powers are attributed, reflecting the iconography of Mulier Amicta Sole. The paper concludes that the form of Virgin Mary taking shape in the ritualized communal visions does not only incorporate the concept of the Virgin Mother of God but also the one of the pre-Christian ancestress. By methods of comparative mythology and ritual analysis, employing written sources this paper makes an attempt to present how in their deer chasing origin myth, the Huns and Hungarians worshiped the ancestress in the figure of the doe, which they identified with the sun. The conclusion of the study is that the primeaval connection of the sun with the ancestress was adopted into Christianity reapearing in the ritualized communal visions.
\end{abstract}

Key words: Christianised rite; ancestress cult; mythology; transformation; Bronze Age; Central Eurasia; Hungarians
ATTILA MÁTÉFFY

Hacettepe University in Ankara, Turkey E-mail: atilla.mateffy@gmail.com This work was supported by the author's own resources. No competing interests have been declared.

This is an Open Access article distributed under the terms of the Creative Commons Attribution 3.0 PL License (creativecommons.org/licenses/by/3.0/pl/), which permits redistribution, commercial and non-commercial, provided that the article is properly cited. (C) The Author(s) 2015.

Publisher: Institute of Slavic Studies, Polish Academy of Sciences [Wydawca: Instytut Slawistyki PAN] 


\section{MARYJA MATKA BOŻA W SLOŃCU O ŚWICIE: "DRAMAT OBRZĘDOWY" U CSANGO NA WĘGRZECH}

\section{Streszczenie}

Artykuł dotyczy określenia źródet i symboli niejednorodnego obrzędu "Patrzenia w Stońce o świcie" wykonywanego co roku w trakcie Zielonych Świątek w ramach odpustu w Csíksomlyó (Şumuleu Ciuc w Rumunii), organizowanego przez Kościół katolicki. Obrzędu wykonywanego również dziś, głównie przez kobiety należące do grupy etnicznej Csango na Węgrzech, które w trakcie wspólnych wizji często dostrzegają postać Maryi Panny we wschodzącym Słońcu. W lokalnym kościele oo. franciszkanie przechowują XVI-wieczną figurę Matki Bożej odzwierciedlającą ikonografię Mulier Amicta Sole, której przypisuje się cudowną moc. Autor artykułu wskazuje się, że postać Maryi Panny nabierająca ksztaltu w zrytualizowanych wspólnych wizjach odnosi się nie tylko do koncepcji Bogarodzicy Dziewicy, ale do jednej z przedchrześcijańskich przodkiń. Dzięki metodom komparatystyki mitologicznej i analizie rytuałów zawartych w źródłach pisanych artykuł ten stanowi próbę omówienia, jak w micie o pogoni za jeleniem Hunowie i Węgrzy czcili tę przodkinię w postaci łani, którą utożsamiali ze Słońcem. Konkluzją artykułu jest to, że pierwotny związek Słońca z ową przodkinią został przejęty przez chrześcijaństwo i przywrócony w zrytualizowanych wspólnych wizjach.

Stowa klu c zo we: obrząd; kult przodkini; mitologia; przobrażenie; Eurazja Środkowa; Węgrzy

\section{THE SHORT HISTORY OF THE CATHOLIC CSÍKSOMLYÓ INDULGENCE}

T

he origin of the East-Transylvanian Catholic Indulgence of Csíksomlyó (Şumuleu Ciuc, Harghita County, part of Romania since 1918, earlier Kingdom of Hungary [1000 AD-1918] and Austro-Hungarian Empire [1867-1918]) organized yearly on Pentecost Saturday is unclear, according to the most often voiced narrative it has been celebrated since 1567 (Mohay, 2005, pp. 107-108). . The earliest written data on the organization of the indulgence is dated from 1649 (Tánczos, 2011, p. 1; based on Mohay, 2009, pp. 140-142). The Pilgrimage Church and Monastery of the settlement, established in 1442 by the Observant group of the Franciscans was dedicated to Virgin Mary, the patron of the Christian feast day in 1448, thus the Visitatio (in Hungarian: Sarlós Boldogasszony) is the date of the indulgence till this day. Above the main altar of the church stands the revered statue of Mary made around 1510-1515 in Csík County (in Romanian: Ciuc; Tánczos, 2010), which is the representation of the theological doctrine of the immaculate conception identified by the iconographic-theological literature with the term Mulier Amicta Sole ("the Woman clothed with the Sun"). The Pentecost indulgence that takes place in Csíksomlyó every year is the manifestation of the cult of the Immaculate Virgin Mother venerated as the Woman clothed with the Sun (Tánczos, 2010). As mentioned already in

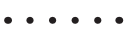

There is more text tradition to rely on with some reservations, as there is a number of internal contradictions and inaccuracies in them. According to the most common narrative about the holiday, the origin of the Pentecost Saturday pilgrimage goes back to 1567, when John Sigismund of Transylvania tried to convert the Csík Székely people to Unitarian faith by force. However, the Székely triumphed in the battle. During the time of the battle of children and the elder were praying at the church, and when the victorious army returned they received the branches of victory. The victory was thanked for before the miraculous statue of Mary, and the memorial celebration of this event became led to the formation of the Pentecost Saturday pilgrimage to Csíksomlyó as we know it today. 
1444 by a circular letter of Pope Eugene IV-in which he expresses his respect towards Mary in great length, a great number of devouts came together for devotion. As early as in 1744 about 5,000 Csango people peregrinated to this indulgence (Tánczos, 2011, p. 2; Gegő, 1838, p.), while the Csíki Lapok² writes in 1894 about the participation of 8-10 thousand devouts at this time. The Roman Catholic Episcopate established in 1844 in Jászvásár (Romanian: Iaşi, laşi County) expressed its rebuke from the very beginning due to the Hungarian national character of the indulgence and the fact that the ceremonies were held in Hungarian, by the 1930's it made attempts to obstruct passage to the site of the indulgence, and starting from the 1980's it was organizing a local indulgence to keep the Csango away from the Csíksomlyó Indulgence (Tánczos, 2011, p. 7). According to reports at 16th of June 1946, after the end of WWII an estimated 150,000 people peregrinated to the indulgence (Csíksomlyó—a "másik oldalról" nézve), ${ }^{3}$ and another tens of thousands in 1949. Throughout the years of Communism in Romania (1946-1990) the Romanian Communist Party sought to prevent the participation of the faithful at the indulgence through the most diverse methods. ${ }^{4}$ After the fall of the Communist Dictatorship in 1990 several hundred thousand Hungarians from all around the world came to attend to the open air Mass and procession, and to say their request in front of the Woman clothed with the Sun-statue in the Franciscan church.

\section{ABOUT THE ICONOGRAPHY OF MULIER AMICTA SOLE ("THE WOMAN CLOTHED WITH THE SUN")}

The statue of Csíksomlyó was made according to Mulier Amicta Sole iconography spread all over Europe: 12 stars over the head of Mary who stands on a crescent Moon with the baby Jesus in her arms. This image-type is a symbolic representation of the Immaculate Conception, and it appears first in the work of Speculum Humanae Salvationis (Mirror of Human Salvation; between 1309 to 1324; Szöllőssy, 1991, p. 18). Although iconographically it in fact originated from The Apocalypse of John (The Book of Revelations) ("12:1 And a great sign was seen in heaven: a woman arrayed with the sun, and the moon under her feet, and upon her head a crown of twelve stars") (Revelation 12:1), ${ }^{5}$ the popular cult of Mother Mary, represented by it replaces the former ancient goddess of the Central Eurasian cosmology, the mother goddess of origin myths (Szöllőssy, 1991, p. 19), as clearly attested from Hungarian historical and ethnographic data. ${ }^{6}$ The ethnographer Vilmos Tánczos captures well the causes of the spread of the iconography among the Hungarian people:

-

2 Published in Csíkszereda (Romanian: Miercurea Ciuc) between 1888 and 1944.

3 The massive participation can be explained by the Paris Peace Treaty (7th May 1946), which approved the Hungarian-Romanian border of 1938, and this time Hungarian members of Protestant denominations also demonstrated against the Paris decision too, not only the Roman Catholic Hungarians of Transylvania. This time the previous religious orientation of the indulgence is expanded with national political profile.

4 The harassment by Romanian governments did not stop completely till this day. The author of these words attended the indulgence of 2006 with his two children, when weeks before the event devouts were being discouraged through media from attending by weather reports of bad rainy weather for the weekend of the indulgence. In the weekend of the indulgence they closed the busiest and direct road section leading to Csíksomlyó, so the crowd was forced to approach the church holding the shrine through a long detour.

5 New American Standard Bible: 1 A great sign appeared in heaven: a woman clothed with the sun, and the moon under her feet, and on her head a crown of twelve stars; 2 and she was with child; and she cried out, being in labor and in pain to give birth.

6 For example in 1345, "the Tatars defeated by the Székely declared that they were defeated not the Székely, but by a night in a big horse holding an ax in his hand (King St. Ladislas), over whom a gorgeous crowned beauty queen (Virgin Mary) floated" (Source: Matthias Florianus, 1884, quoted after Endes, 1994, p. 25). 
the religious approach of the people characterized by less intellectual and more emotional bases (...) could accept without reservation and could combine the Immaculata imagery idealized by the Church and the maternity concepts that derived from the pagan fertility goddesses in a single Mary-image (Tánczos, 2010a).

Csango Hungarians address Virgin Mary and the statue of the Csíksomlyó shrine (Daczó, 1980) as Babba Mária, ${ }^{7}$ which is surrounded by a special reverence. After repeated investigations led by the church in the second half of the 18th century (responding to popular initiative) the Csíksomlyó Statue of Mary was declared miraculous in 1798 by Batthyány Ignác Transylvanian bishop (Tánczos, 2010b).

\section{ABOUT THE MOLDAVIAN CSANGO HUNGARIANS}

"Csángó" is the common name of several Hungarian-speaking minority ethnic groups living in Romania. They have three main groups: the Moldavian Csangos, Gyimes Csangos and Barcaság Csangos (Romanian: Tara Bârsei). They number about 320,000 persons, of which only about 80-90,000 still speak Hungarian (Csángók, n.d.). They speak a dialect of the Hungarian language — the most endangered Hungarian dialect, that preserves a multitude of archaic traits. Several hypotheses have been suggested about the origin of Csángós, but it is unnecessary to discuss this matter here. Most of the so-called Csángós moved to Moldavia as a result of the Székely Hungarian wave of refugees of the 1764 "Peril of Madéfalva" (Siculicidium, n.d.). They settled amongst the Csango Hungarians already living in this region. Their "Csango" ethnonym has first been recorded in the 15th century. The Csíksomlyó pilgrimage has been traditionally visited by the Csangos in the biggest number, traditionally after having peregrinated through the distance between their abode and the celebration site on foot. They live in the province of Moldavia (Romania), and by religion they are Roman Catholic. ${ }^{8}$ Their identity is based on their Roman Catholic religion, while the Romanians, constituents of the national majority are of Orthodox faith.

\section{A SHORT DESCRIPTION OF THE "LOOKING INTO THE SUN AT DAWN" RITE OF THE MOLDAVIAN CSANGO PEOPLE ${ }^{9}$}

The Moldavian Csango "Looking into the Sun at Dawn" ritual practiced in the morning of Pentecost is well integrated into the traditional custom order of the Csíksomlyó pilgrimage. The Moldavian Csango believe, that they can see the Holy Spirit flying into the Sun in the shape of a dove, as well as the shapes of Jesus, and Virgin Mary and other holy things at the dawn of Pentecost on the eastern slope of the Kis-Somlyó mountain (Peti,

\footnotetext{
7 in th

In the Hungarian Csango dialect that preserves many archaisms; the meaning of the word "babba" means "beautiful", "bright", "pure" (Tánczos, 2010a).

8 The core of group is probably a remnant of the Hungarian border guards left on the border region at the time of the Hungarian conquest of the Carpathian Basin, the ranks of whom was later, in the 12-13th century enforced by Transylvanian and Upper-Tisza region Hungarians. After 1764 another thousands of Székely (Hungarian speaking ethnographic group) families settled with them fleeing from the Transylvanian Székelyland.

9 The core of group is probably a remnant of the Hungarian border guards left on the border region at the time of the Hungarian conquest of the Carpathian Basin, the ranks of whom was later, in the 12-13th century enforced by Transylvanian and Upper-Tisza region Hungarians. After 1764 another thousands of Székely (Hungarian speaking ethnographic group) families settled with them fleeing from the Transylvanian Székelyland.
} 
2010). Until the 2000's they came mostly from several settlements, from a distance of $115-175 \mathrm{~km}$ on Friday to the site of the indulgence on foot, singing the song starting with the lyrics Zeng az erdö, zeng, zúg a levele, Mária örömére... ('Resounds the forest, resounds, its leaves are whizzing, to Mary's delight') on their way (Tánczos, 2011, p. 1). The tired pilgrims, having been deprived of sleep during the consecutive days of prayer, under the influence of the recitals of holy acts, fall into a kind of ecstatic, emotionally elated state by the time they arrive to the place of the devotion (Tánczos, 2011, p. 9). In the Salvator Chapel, located on the Kis-Somlyó mountain, approximately 700 meters away from Csíksomlyó, or wrapped into blankets around the chapel they spent the last hours before the Sunday sunrise singing and praying, at times archaic apocryphal folk prayers were also spoken (Tánczos, 2011, p. 20). Until the early 2000's they used to pray and sing in Hungarian, nowadays it is mostly in Romanian (Tánczos, 2011, p. 1), since the old generation of Moldavian Csangos that new the Hungarian-language liturgy has died (Tánczos, 2011, p. 8). At sunrise they stare fixed for several minutes through smoked glass, sunglasses, handkerchiefs or the tip of a headscarf. Whoever reckons to have seen something makes an account of these experiences to the others, which they interpret and complete with their own associations. In case of cloudy, gloomy weather the looking into the Sun falls short of certain ritual elements, and such times are explained with the fact that Mary is angry! The Holy Spirit is Sad! The Gyimes Csangos also attended the waiting for the Sun, although in fewer number than the Moldavians, but the Szekely did not know the rite. In Moldavian villages the modernizing effects of the past few decades have played a major role in the decay of the cosmology based on the traditional religious values (Peti, 2009). The fact that the indulgence became a mass event and the often intrusive appearance of mass media added to this, leading to the transformation, simplification (Tánczos, 2000) of the traditional ritual order of the Csango "ritual drama" (Tánczos, 2011, p. 9). ${ }^{10}$ The "drama" of the indulgence that serves as context to the "Looking into the Sun" rite does not only happen at the shrine, but also in other spaces: in the homes of the participants at the indulgence, in the public spaces of the villages, in the other churches and chapels visited during the time of the peregrination (Tánczos, 2011, p. 9):

1. Departing to the indulgence;

2. The Road to the Indulgence: Via Sacra;

3. Arrival, the Greeting of the Statue;

4. The Touching of the Statue;

5. Confession, Communion;

6. Stations of the Cross;

7. The Procession;

8. The Laborium;

9. Waiting for the Sun before the Morning of Pentecost;

10. Herb Gathering;

11. Saying Goodbye to Mary (Tánczos, 2011, pp. 10-20);

12. Homecoming.

10 There are detailed descriptions of the rite in Hungarian, the publication of which would be problematic for reasons of space, therefore here I will quote their shortened synopsis only. 


\section{THE RELIGIOUS ANTHROPOLOGICAL INTERPRETATION OF THE RITE ON THE BASES OF THE LITERATURE ABOUT RELIGIOUS VISIONS AND DREAMS}

The ritual of "Looking into the Sun" of the Csango people serves the intensive communication with the supernatural. Visions, in accordance with the international material are also a part of the religious system of interpretation in the Csango communities, socially legitimate forms of direct communication with the transcendence (Peti, 2009, footnote 45). Communal visions are conditioned by the cultural forms and models, since they are used in the public structure of a culture. Earlier research has shown that between communal or private visions and dreams and fairy tales, as well as myths an intensive interaction can be detected, and the different dream-stories of individuals not only resembled each other, but also they showed important similarities with some well-known tale types (Stewart, 1997, p. 879; Peti, 2009).

According to Barbara Tedlock's observation the dream and vision narratives often involve mythological motifs (Tedlock, 1992, p. 463; Peti, 2009, footnote 36). The visions (as well as dreams; vide: Tedlock, 1981, p. 314) function as cultural representations similarly to other mythological and divinatorical texts waiting to be interpreted. Dorothy Eggan examined the appearance of mythological knowledge in one's dreams and fantasies. The author believes that the relationship between the individual and "folklore" thus implemented can be called "socialized fantasy" (Eggan, 1955). With relevance with these observations in the Hungarian folklore literature the typologizing motif analysis, the identification of the motifs in the epic tradition prevails as the dominant approach while analyzing dreams and visions. The cultural content revealed in the visions consists of symbols and historically determined notions also present in the Moldavian Csango religious folklore; it is a sort of "community symbolism" (cf. Peti, 2009). The actions of the ritual drama (that the Catholic indulgence is) bring forth the transformation of space and time: a sacred time and space is created (Tánczos, 2011, p. 9).

The visions have lost a lot from their epical expressiveness and motivic abundance in the second half of the 20th century, especially during the past 25 years.

\section{THE NARRATIVE ELEMENTS OF CSANGO HUNGARIAN COSMOLOGY REFLECTED IN THEIR COMMUNAL VISIONS}

According to the folk traditions of the Hungarian people they are originated from the Huns (Ortutay, 1977-1982), ${ }^{11}$ while in the chronicles of the ruling dynasty of the Kingdom of Hungary, the Turul ${ }^{12}$ Kindred (? -1301 AD; Kézai, 1999, pp. 81, 159, 227; Mátéffy, 2012, pp. 957, 958 fn. 2) written in Latin, containing mixed genre elements (12th-13th centuries), Hungarians are themselves called Huns. ${ }^{13}$ The origin myth of Hungarians shared with the Huns is the legend of wonderful deer. ${ }^{14}$ Spread throughout a vast area due to

11 Footnote 45 (Tánczos, 1996, pp. 42-55). "Theatrum sacrum” (Tánczos, 1996, pp. 42-55).

12 Article names of Attila; Csaba-legend; Wonder-deer; The Road of Armies; Huns; Hun-Magyar Myth Group; Hunor and Magor, Hunor and Magyar; Milkyway (Lat. Via Lactea). Cf. also Hóman, 1925.

13 Toğrı "a bird of prey" (Clauson, 1972, p. 472).

14 Anonymus: Gesta Hungarorum (ca. 1200 AD): „Attila rex Hungarorum”; Simon of Kéza: Gesta Hunnorum et Hungarorum (The Deeds of the Huns and Hungarians; 1282-1285 AD): "Huni sive Hungari, Hunos sive Hungaros" (Huns or Hungarians); in Europe: Thomas the Archdeacon (historian and chronicler from Split/ Spalato; ca. 1260 AD): „Huni, postea Hungari”, etc. 
its ancestral age, has most of its variants-and motivically the richest ones-registered among the equestrian nomadic herdsmen peoples of the Central Eurasian steppe region and South Siberia or their descendants (cf. Mátéffy, 2012, pp. 943-944). The structural scheme of the myth group can be reconstructed as follows:

1. a royal person (hunter) chases a wonderful (white/fanciful colored, etc.) hind (Aarne, 1910; Berze Nagy, p. 401; Thompson B184.4. Magic deer. Irish myth: Cross.; B731.)

2. due to some unseen force he can not drop the hind;

3. the hind leads the chaser to the other side of a river/shallow/lake/mountain range (Thompson B562.1. Animal shows man treasure; B563.4. Animal leads cleric to holy place);

4. in the most archaic versions there it turns into, or regains the shape of a princess; (Thompson D114.1.1.1. Transformation to deer [fawn] [by druid] Irish myth; D114.1.1.2. Transformation: woman to doe. India: Thompson-Balys);

5. the chasing prince marries this princess (Thompson B601.10. Marriage to deer. Irish myth: Cross.; B640. Marriage to person in animal form. B641.2. Marriage to woman in deer form [Cf. D114.1.] Irish myth: Cross, MacCulloch);

6. and they establish a new home / clan in this abundant territory shown by the hind (vide: Thompson B562.1. Animal shows man treasure. Irish myth: Cross., etc.).

The key element of the myth group is the transformation of the doe into a woman, and her marriage to the cultural hero. This ancient core is rooted in millennia old astral myths, and its traces could be detected until recent times in various oral epic creations. Some of the Hungarian folk tale types (collected mostly in the 19th-20th century) also retained many of its fundamental features. In a Csango tale from Tatrang (Romanian: Tărlungeni; Horger, 1908, p. 373; Berze Nagy, n.d., p. 128) on the top of a tall tree (motif: World tree) over the Sun's abode in the sky a fairy by the name of Tündér ${ }^{15}$ /lona lives (the survival of the figure of the Ancestress), who bathes (Water of Life) the Gypsy (the survival of the figure of the ancient Culture Hero) that climbed the tree, and they become husband and wife (the survival of ancient totemistic marriage between the Doe/Ancestress/Sun and the Culture Hero).

In a Csango version from Zajzon (Romanian: Zizin; Horger, 1908, p. 422) on the top of a big tree there is a Golden City (symbol of the Sun), with a golden castle, in it a church. A mistress (Ancestress) lives here. The girl becomes the wife of the lad who climbed the tree. In many Hungarian variants of the same folktale (Aarne, 1910, p. 16 [Type 400: Gattin/'Schwanenjungfrau']; cf. Bäcker, 2007, pp. 311-318, with excellent bibliography) the female protagonist is even called Sun Girl. The woman character of myths and tales, with bright face living in a shining palace is the symbol of the Sun that lives in the highest sphere of the sky (Berze Nagy, n.d., pp. 130-131). In other variants the role of ancestress or mother goddess remains even more emphasized: in a Székely variant Tündér Erzsébet, ${ }^{16}$ preserving the image of the eastern pre-Christian rejuvenation rejuvenates her sweetheart (Berze Nagy, n.d., p. 138) who grew old, while in another Székely variant on the top of a tree (again, the world tree, climbed by the shaman in shamanistic cultures during shaman-rituals to mediate the wishes and prayers of the community he represents to the gods living in the highest celestial sphere) that touches the clouds a bird with golden feathers is hatching eggs (the symbol of the Sun; Berze Nagy, n.d., p. 140). This

15 Vide: Mátéffy, 2012, pp. 942-943: Salaminius Hermias Sozomenus: The Ecclesiastical History, Book VI-Chap. XXXVII (Concerning the Barbarians Beyond the Danube, Who Were Driven Out by the Huns; ...); Procopius of Caesaerea: History of the Wars: Books VIII (The Gothic War); Jordanes: The Origin and Deeds of the Goths, XXIV (122).

16 The meaning of Hungarian "tündér": 1. "gorgeous", "bright", "shiny"; 2. "fairy". 
is clearly a survival element of the ancestress image of the Sun-symbol. These are the words of the tale-researcher and folklorist János Berze Nagy about this matter: "Apearing in the shape of a great bird ${ }^{17}$ - a shape she is capable to change, of supernatural beauty and might, walking the highest celestial sphere, the one of the Sun, the golden blond woman of the Hungarian folktales is usually Tündér llona (...)" (Berze Nagy, n.d., pp. 144145) exhibiting the traits of the main deity of astral myths (or rather the main female goddess, the Ancestress). In a variant of Besenyőtelek (Hungary, Heves County) when the protagonist wanted to cut a great tree, a door opened on the tree and an old woman peeked out from within, whom he later addressed as "my old mother" (öreganyám). She called him "my boy" and encourged him to climb the tree. On the top of the tree there was a great fairy garden, in the middle of the yard a castle, behind it a great lake. One of the three swans who came here to bath was Tündérszép Ilona, who marries the protagonist (Berze Nagy, n.d., p. 161). The Yakut (or Sakha; in Northern Siberia) variants represent a somewhat more archaic degree of developement. In these there is a great tree in the Earth's navel, from which a female creature (ein weibliches Wesen) emerges to tell the protagonist approaching the tree that he came to this world to become the father of all human race (Harva, 1938, pp. 74-75). Other versions feature an old white-haired goddess (Harva, 1938, pp. 77-78). In the Yakut myths the goddess living inside the tree is called the same way as the goddess of giving birth: Kübei-Khotun (Harva, 1938, p. 82; Berze Nagy, n.d., p. 273). Quite fascinating parallels of this ancient folk belief was found among the Gyimes Csango Hungarians. According to their belief it is Babba Mária (Mother Mary) who relieses the cow when it is giving birth (Daczó, 1980). A Csango man said that before his wife would give birth they always pray to Babba Mária, and also added, that whenever a woman is about to give birth they always pray to Babba Mária. Any man suffering innocently awaits for the help of Babba Mária (Daczó, 1980, pp. 234). Quoting from Priklonskij, Pekarskij, Seroševskij (Sieroszewski), etc. Uno Harva enumerates the same attributes of the Yakuts almost word by word: the goddess (Kübäi-khotun) gives strength to the lonely man, fertility and easy childbirth to women and guides the fate of the newborn (Harva, 1938, pp. 168-169). But the gist of the content of the millennia old wonder deer myth preserved in the Hungarian oral traditions lives as oral rite text as well as folk tales. The constant motifs of the 'regös songs' (Songs of Fertility; Sebestyén, 1902, p. 71; Sebestyén, 1904-1905/2001, p. 156) collected in more than a hundred variants: the part of the magic meant to provide fertility, in which they wish fertility and abundance to the owner of the house and its other inhabitants, moreover a matching part in which they conjure the unification of a lad with a girl through a regös song (motif of marriage). In the introduction part the regös (the Singer of the Songs of Fertility) tell about the long way they made to come as God's messengers or Saint Stephen (Stephen I of Hungary; Turul Kindred) servants. The part relating about the wonder deer is also a told in the epic introduction. The candles on its horns inflame without being litten, turn off without extinguishing, and carries the Sun and the moon on its body. Sometimes they ask Saint Stephen not to shoot at them (Ortutay, 1982, pp. 330-332). The same ancient Central Asian content appears in oral marrying ritual texts among the Csangos; the groom with his friends visit the house of the bride to account of a deer (or a stag) ${ }^{18}$ wounded during a hunt, its traces led right here and now they ask for the wounded game. The events finally end with the marriage of the "hunter" (groom) and the "deer" (doe; bride).

17 The names of Tündér llona and Tündér Erzsébet are folklore variations of each other

18 See the Holy Ghost flying in the shape of a pigeon during the Pentecost 'Looking into the Sun at Dawn' Rite. 
This archaic tradition of asking a girl into marriage was vivid until the 1950/60s, at the time of the marriage of the eldest generation still living in the community (Laczkó, 2004, pp. 291-292; Mátéffy, 2012, p. 955).

The above presented cult of the doe richly documented in the oral culture of Hungarians descended from Central Asia (Bíró, Zalán, Völgyi, \& Pamjav, 2009) was present in their culture long before their first encounter with Christianity at the Azov Sea (Lake Maeotis, city of Bosphorus; 6th c.) and North Caucasus (6th-10th centuries). The solar orb is mostly a female symbol in the Turkic and Altaic ${ }^{19}$ peoples traditional culture (Harva, 1938, pp. 182-183, 187-188); the Nart Epic ${ }^{20}$ of the North Caucasus Ossetians (generally considered the descendants of the Schytians and Alans) may be a syncretic (TurkicIndo European) survival element, where the doe turn into the daughter of the Sun-God. In Bulgarian folklore, partly a progeny of the Huns (Bulgarian Turkic) in a carol collected in the 20th century (koleda) a stag with golden horns appears, with the Sun on his forehead, the Moon on his chest, and the stars on the stars on its antlers (Berze Nagy, 1927, p. 147). In the Hungarian 'regös songs' candles burn on the antlers of the wonder deer, and it bears the Sun and the Moon on its body. The Bulgarians and the Hungarians brought all these ancient motifs from Central Asia through the Caucasus and the Azov Sea region to Europe, the later already religiously united in Christendom at the time. In Southern Europe where the Sun (Helios) is the male symbol and the female symbol is the Moon (Selene) as an ancient Greek legacy. ${ }^{21}$

At the coronation Stephen I (reigned 1000/1001-1038 AD) Western Christianity became the state religion in the Hungarian Kingdom. It says in the Great Legend of Saint Stephen (beginning of the 12th century; Érszegi, 1983, pp. 34-53) that the king left without a successor offered Hungary into the protection of Mother Mary, addressed as "Queen of Heaven" in his prayer (Érszegi, 1983, pp. 48-49). This is the origin of the old Catholic expression "Regnum Marianum" ("The Country of Mary") denoting Hungary. It can be found on the page 136 of the Halotti beszéd és könyörgés (Funeral Sermon and Prayer), the oldest Hungarian coherent text, included in the Sacramentarium called Pray Codex written in Latin. This is where the following part is featured: And we worship the Holy Virgin Mary. It is obviously based on these data that the Mary cult (Tánczos, 2010a) was already known by the Hungarians at the time Christianity became the state religion, preserved till this day in the isolated culture of the Csango Hungarians. ${ }^{22}$ The also archaic Boldogasszony expression was generally used among the Hungarians for Mother Mary. The Hungarian "boldog" corresponding to the Latin beatus used to mean "provided with

19 In the Korean Mythology Hae(sik)-nim is the Sun, the sister of the Moon.

20 The Nart Epic tradition lives amongst the North West Caucasian Abkhaz, Adyghe, Chechen, Circassian, Karachay-Balkar, Ossetian, Ubykh people.

21 But Károly (Karl) Kerényi wrote: "Doch war auch Helios, der Gott 'Sonne', mit dem menschlichen Sein inniger verwoben als der Himmelskörper "Sonne " außerhalb der Mythologie es sein konnte. Nicht nur weil er unwillkürlich mit menschlichem Maßstab gemessen und im menschlichen Bilde gesehen wurde! Nach diesem Maßstab galt er als »unermüdlich«, ein unermüdlicher Wagenlenker, ursprünglich Lenker eines Stiergespannes und erst später der von "feuersprühenden Rossen«. Von außen her verwoben war er mit unserem Leben als Quelle des Augenlichts, als "zeugender Vater der Sonnenstrahlen «, verwoben war er aber auch von innen, von einem tieferen Grund her, als ob unsere Augen selbst von der Sonne, dem "unermüdlichen Auge», herstammten. "Sonnenstrahl du, vielschauende Mutter der Augen « - so begann unser großer Dichter Pindar einen Paian, eines jener Lieder, die zu Ehren Apollons gesungen wurden. Es war nicht von vornherein ausgeschlossen, eine mütterliche Gottheit in der Sonne zu erblicken. Es war in unserer Sprache sogar eine Helia, ein weiblicher Name mit der Bedeutung "Sonne" möglich, der name einer der Töchter der Sonne, Schwester des Phaethon; denn die Sippe des Helios wies viele göttliche Mädchen und Frauen auf" (Kerényi, 1951/1966, p. 151).

22 The second oldest Hungarian language monument also relates to the ancestress symbol Virgin Mary; preserved in the Leuven Codex (last third of the 13th century) it is the so called Lamentations of Mary (Vizkelety, n.d.). 
something," "rich," "thick," "pregnant," while the word asszony [assoń] ${ }^{23}$ copied from the Iranian Alans (the ancestors of the Ossetians) cohabiting with Hungarians in the Caucasus until the 10th century meant "mother" innitially (Tánczos, 2010a). The Csango ethnic group of Hungarians address the same person as Babba Mária: the goddess identified with the Sun, the Ancestress.

\section{THE MOST ANCIENT MONUMENTS OF THE RITUAL CONNECTION OF THE DEER AND SUN}

In the culture of the South Siberian and Central Asian peoples the deer (as well as the hunter) appears as a celestial body (Berezkin, 2005, pp. 79, 83-86) and the early Central Asian Bronze Age "Deer Stones" also represented images of beaked deers swimming towards the Sun. The sometimes over emphasized antlers of the deer that can encompass the entire animal often hold a sun disk or other images representing the Sun, thus expressing the so common association in Siberian Shamanism between the deer and the Solar orb. Often adorned with bird-like imagery the deer seems to have served as a spirit guide capable of transcending from Earth to the sky, just like the shaman that it stands for, mediating between the spheres.

The words of William W. Fitzhugh, an archaeologist studying Bronze Age deer stones of the Sayan-Altai and Western-Mongolia, are meaningful, therefore I should quote him:

[The] deer stone art illustrates many features of the lives and technology of these late Bronze Age peoples, analysis sheds light on the question of animal style art and its links with shamanism, ceremonialism, reindeer breeding, hunting, animal-human transformation, ritual sight, and other features characteristic of circumpolar art and culture (Fitzhugh, 2009, p. 73).

\section{And than so:}

Shield-like motifs resembling... often found... skeletal designs on shaman drum beaters. (...) The rare depictions of human faces are usually seen with rounded, open mouths-as though singing or chanting -and seem likely to represent shamanistic power or séance. The deer-bird image also suggests spiritual transformation (cf. Kerényi, 1930, pp. 145, 147-148; Mátéffy, 2012, pp. 951-952) experienced in shamanic flight in the passage from earth to sky, or the passage of the soul of a deer stone personage from earthly life to the heavens after death. (...) horse head burials always have the muzzle facing east or southeast (Fitzhugh, 2009, p. 77).

The use of the deer theme in rock art indicates that the 'deity' must have broader import than simply for mortuary and commemorative ritual; apparently it must have been a central deity in the spiritual lives of south Siberian and Mongolian peoples, perhaps serving for several millennia as the 'deer goddess' of Bronze Age Siberia, as argued by Jacobson (Fitzhugh, 2009, p. 85; cf. Jacobson, 1993).

The main charateristics of the South-Siberian and Mongolian deer stones: they always are oriented to east, they present the deer-bird-Sun-goddess transformation and they served the spiritual needs of the late Bronze Age community that created them.

This ancient, perhaps universal spiritual seed is the antecedent of the Hungarian Mother Mary Cult in the millennia before embracing Christianity.

3 Hungarian: asszony [assoń] (1150 AD, 12th C. AD) „wedded woman, woman, mrs.” — Ossetian: xšinn,

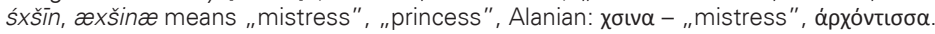


Vilmos Tánczos describes in one of his works as amongst the Székely of Csík and the Gyimes Csángó Babba Mária also posesses the attributes of a Moon-deity (Tánczos, 2010a); for instance they call the moonlight "the lamp of Babba Mária" (Daczó, 1980, pp. 235-237 [points 6-8]). Although I think that these are also important data, and it is worth further studying its associations, they do not decisively effect associations on a larger space and time scale. There are always inconsistancies in folk culture, and from the earliest times the cosmology of a people, its beliefs or even more generally its culture is affected by outside influences; in addition the changes do not only occure due to outside influences but-reflecting one of the main features of folklore phenomena, through inner variation as well. As Uno Harva also said: Turkic people only generally regard the Sun as a female principle ("die meisten türkstämmigen Völker"; Harva, 1938, p. 182). But than the Chuvash leading an agricultural way of life, at on time sacrificed white neat (weisses Vieh) to "Mother Sun" (Mutter Sonne; Harva, 1938, p. 183). The white bovine had a cultic role in the entire nomadic steppe culture, including that of Hungarians, and so we have planty of data about white deer, cattle or horse-sacrifice. The Chuvash data makes the associative system of the Hungarian folktales (including the Csango) more comprehensive. In addition, the head of the so called "round Madonna" type attributed to naive Csango folk art is resembling the roundness of the sun disk, thus refers to the source of life (Napbaöltözött Asszony, n.d.). ${ }^{24}$ The phrasing of the second question was inspired by János Berze Nagy, folklorist and researcher of folktales. In his book, in a chapter named "Mother-Goddess and the Hungarian Mary-Cult", he emphasizes several times that innitially the main deity was sitting on the top of the tall and wide tree from the tales, and his attributes were later inherited by the Mother-Goddess (Berze Nagy, n.d., pp. 125-126) (cf. Radloff, 1954; Harva, 1938; Karjalainen, 1922). This positive statement founded on great reading and professional deftness at this moment I can not refute based on my present knowledge, and I do not want to. But if this transition has actually happened, it must have occurred very early, before the Bronze Age. At the time when folklore researches started in Siberia and Central Asia the mythological role of the main deity and the mother goddess is unstable, they mutually show the features of each other; it is difficult to decide which one is older. However, it is the Mythology of Turkic Peoples where it conspicuously seems that the deer/ancestress cult probably inherited from the eastern Scythians (the Saka and the Sauromatae; Harmatta, 1999, pp. 389-390) is more archaic, and the raptorial bird/wolf cult is younger, a formation reflecting the patriarchal steppe social arrangements that evolved after the formation of equestrian nomadism (not earlier than 1500-1300 BC and after it the Cimmerians).

The doe imbibes the traditional culture to its very core from Yakuts to Anatolian Turks and right to Hungarians, while the mythological role of the wolf seems to be more obscure. To respond to the two question with a single phrase, at this point my stance is that in the examined ritual and epic material, and also on the discussed geographical area the Sun-goddess-doe-bird(not of prey)-ancestress symbolic correspondence prevails with absolute dominance in the 5 millennia long era from Bronze Age to present.

\footnotetext{
- ....

24 Hungarian Catholic Lexicon, the entry "Woman clothes with the Sun."
} 
Based on the ethnographic and historical data the narrative motifs of the wonder deer myth was preserved in various oral folklore genre, myths, tales, matching ritual text, and fertility-magic ritual songs. This wonder deer origin myth is shared with the Huns by the conqueror Hungarians, who brought it as vivid oral tradition to their homeland from the east in the last decades of the 9th century after a planned migration. As the motifs of the totemistic (animalistic) origin myth rooted in the pre-Bronze Age Central Eurasian ancestress cult encompass every layer of the whole traditional culture, so it was preserved as survival elements of folk religion, folk Christianity. The 9th century Hungarians living a steppe pastoral-agricultural, seminomadic lifeform developed a kind of religious synchretism adapting and assimilating cultural goods step by step to its previous cultural complex as a part of the acculturation process started on the steppe regions north from the Black Sea and in the Caucasus mountains, when first adopted notions of eastern and then western Christianity, already in the Carpathian Basin. This time, innitially all Hungarians, and then-due to geographical circumstances, the especially isolated and thus culturally strikingly conservative Csango Hungarians alloyed all these notions of the church supported immaculata-idea with matternal ideas that are rooted in images of pagan fertility goddesses they share with Yakuts and Evenki and Southwestern Siberian Chuvash and other Central Eurasian peoples in a single image of Mary (Boldogasszony and Babba Mária). This pre-Christian ancestress cult served as fertile ground to the spread of European Christian Mulier Amicta Sole types all over Central Europe and to their lasting popularity. And in the Pentecost 'Looking into the Sun at Dawn' communal rite as a result millennia old connections between visions, as well as tales, myths Mother Mary is revealed in the Sun, or the Holy Ghost in the shape of a pigeon, as Tündér Ilona as a swan is also the timeless symbol of the Eurasian ancestress, chased in the shape of a doe by the celestial hunter of the astral myths, the culture hero, and marries her in the shape of a man after transformation for her to become the ancestress of a stem. The deers floating to the Sun are on Central Asian deer stones-always oriented to east are the timelessly rigid monuments of this transformation. Due to the tradition braking effects of religious mass tourism and the ethnic and religious political attitudes to Csangos the Late Bronze Age Shaman rites survived as impoverished communal "ritual drama" to see the 21th century.

\section{REFERENCES}

Aarne, A. (1910). Verzeichnis der Märchentypen (FF Communications, 3). Helsinki: Suomalaisen Tiedeakatemian Toimituksia.

Bíró, A., Zalán, A., Völgyi, A., \& Pamjav, H. (2009). A Y-chromosomal comparison of the Madjars (Kazakhstan) and the Magyars (Hungary). American Journal of Physical Anthropology, 139(3), 305-310. http://dx.doi.org/10.1002/ajpa.20984

Bäcker, J. (2007). Schwanjungfrau. In R. Brednich, H. Alzheimer, H. Bausinger, W. Brückner, D. Drascek, H. Gerndt, I. Köhler-Zülch, L. Röhrich, R. Lutz, \& H.-J. Uther (Eds.), Enzyklopädie des Märchens (Vol. 12, col. 311-318). Berlin, New York NY: Walter de Gruyter. 
Berezkin, Y. (2005). The cosmic hunt: Variants of a Siberian-North American myth. Folklore, 31, 79-100. http://dx.doi.org/10.7592/fejf2005.31.berezkin

Berze Nagy, J. (1957). Magyar Népmesetípusok (Vols. 1-2). Pécs: Baranya Megye Tanácsa.

Berze Nagy, J. (n.d.). A föistenek lakóhelye: Magyar mitológiai tanulmányok. Budapest: Kőrösi Csoma Sándor Magyar Egyetem.

Bosnyák, S. (1973). A felkelő nap köszöntése a csángó népcsoportoknál. Ethnographia, 84(4), 559-563.

Burke, P. (1997). The cultural history of dreams. In P. Burke, Varieties of cultural history (pp. 23-42). Ithaca NY: Cornell University Press.

Clauson, G. (1972). An etymological dictionary of pre-thirteenth-century Turkish. Oxford: Clarendon Press.

Csángók. (n.d.). Csángók: Első írásos említései. In Wikipedia. Retrieved December 18, 2015, from https://hu.wikipedia.org/wiki/Cs\% C3\%A1ng\% C3\%B3k\#Els.C5.91_. C3.ADr.C3.A1sos_eml.C3.ADt.C3.A9sei

Csíksomlyó. (2010, May 23). Csíksomlyó-a „másik oldalról” nézve. Retrieved December 18, 2015, from http://tortenelemportal.hu/2010/05/csiksomlyo-a-masik-oldalrol-nezve/

Daczó, Á. (1980). A gyimesi Babba Mária. In Á. Daczó, Népismereti Dolgozatok (pp. 231239). Bucharest: Kriterion. Retrieved December 18, 2015, from http://www.bucsujaras.hu/tanulmany/daczo/babba.htm

Eggan, D. (1955). The personal use of myth in dreams. The Journal of American Folklore, 68(270), 445-453. http://dx.doi.org/10.2307/536769

Endes, M. (1994). Csík- Gyergyó- Kászon-székek (Csík megye) földjének és népének története 1918-ig. Budapest: Akadémiai Kiadó.

Érszegi, G. (1983). Szent István király intelmei Imre herceghez. In G. Érszegi, Árpád-kori legendák és intelmek (pp. 54-61). Budapest: Szépirodalmi Könyvkiadó.

Fitzhugh, W. (2009). Stone shamans and flying deer of Northern Mongolia: Deer goddess of Siberia or Chimera of the steppe? Arctic Anthropology, 46(1-2), 72-88. http://dx.doi. org/10.1353/arc.0.0025

Florianus, M. (1884). Chronicon Dubnicense cum codibus Sambuci Acephalo et Vaticano, cronisique Vindobonensi Picto et Budensi accurate collatum. Lipsia. Retrieved December 18, 2015, from https://archive.org/details/chronicondubnic00florgoog

Gegő, E. (1838). A moldvai magyar telepekről. Buda: Magyar Királyi Egyetem betúivel. Retrieved December 18, 2015, from http://mek.oszk.hu/06800/06894/06894.pdf

Harmatta, J. (1999). A türkök eredetmondája. Magyar Nyelv, 95(4), 385-397.

Harva, U. (1938). Die religiösen Vorstellungen der altaischen Völker. Helsinki: Suomalainen Tiedeakatemia, Helsinki: Werner Söderström Osakeyhtiö Porvoo.

Hóman, B. (1925). A magyar hún-hagyomány és hún-monda. Budapest: „Studium” kiadása. Horger, A. (1908). Hétfalusi csángó népmesék (Magyar Népköltési Gyűjtemény, 10). Budapest: Athenaeum.

Jacobson, E. (1993). The deer goddess of ancient Siberia: A study in the ecology of belief. Leiden: E. J. Brill.

Karjalainen, K. F. (1922). Die Religion die Jungra-Völker (Vol. 1). Helsinki: Suomalainen Tiedeakatemian Kustantama. (FF Communications, 41)

Kerényi, K. (1930). A csodaszarvas az ezeregynapban. Ethnographia, 41, 140-152.

Kerényi, K. (1966) Die Mythologie der Griechen: Vol 1. Die Götter- und Menschheits-geschichten. München: Deutscher Taschenbuch Verlag. (Originally published 1951). 
Kézai, S. (1999). The Deeds of the Hungarians = Gesta Hungarorum (L. Veszprémy \& F. Schaer, Transl. \& Eds.). Budapest: Central European University Press.

Laczkó, M. (2004). Észre sem vettük, magyarok lettünk. Bonyhád: Egyházaskozári Önkormányzat.

Mátéffy, A. (2012). The Hind as the Ancestress, ergo Virgin Mary: Comparative study about the common origin myth of the Huns and Hungarians. Sociology Study, 2(12), 941-962. Retrieved December 18, 2015, from www.davidpublishing.com/ download/?id=12401.

Mohay, T. (2005). Egy ünnep alapjai. A csíksomlyói pünkösdi búcsú új megvilágításban. Keresztény Magvetó, 111(2), 107-134. Retrieved December 18, 2015, from http://epa. oszk.hu/02100/02190/00202/pdf/KM_2005_02_107.pdf

Mohay, T. (2009). A csíksomlyói pünkösdi búcsújárás. Történet, eredet, hagyomány. Budapest: Nyitott Könyv, L'Harmattan.

Napbaöltözött Asszony. (n.d.). Napbaöltözött Asszony. In Magyar Katolikus Lexikon. Retrieved December 18, 2015, from http://lexikon.katolikus.hu/N/Napba\%C3\%B6lt\% C3\%B6z\% C3\%B6tt\%20Asszony.html

Ortutay, Gy. (Ed.). (1977-1982). Magyar Néprajzi Lexikon (Vols. 1-5). Budapest: Akadémiai Kiadó.

Peti, L. (2007). Ritualizált közösségi látomás: a moldvai csángók napbanézése. Retrieved December 18, 2015, from http://www.hargitakiado.ro/cikk.php?a=MjAy

Peti, L. (2009). Krízishelyzeteket artikuláló vallásos tartalmú álmok egy moldvai csángó településen. Kisebbségkutatás, 18(4), 576-603. Retrieved December 18, 2015, from http://www.hhrf.org/kisebbsegkutatas/kk_2009_04/cikk.php?id=1797

Peti, L. (2010). Moldvai csángók napbanézése. Retrieved December 18, 2015, from http:// lexikon.adatbank.ro/tematikus/szocikk.php?id=61

Pozsony, F. (1998). Látomások a moldvai csángó falvakban. In É. Pócs (Ed.), Eksztázis, álom, látomás. Vallásetnologógiai fogalmak tudományközi megközelítésben (pp. 72-80). Budapest: Balassi, Pécs: Pécs-University Press.

Radloff, W. (1954). Aus Sibirien. Istanbul: Maarif Basımevi.

Sebestyén, G. (1902). Regös-énekek. Budapest: Athenaeum.

Sebestyén, G. (2001). A magyar honfoglalás mondái. Budapest: Magyar ház. (Originally published Vol. 1-2 in 1904-1905).

Siculicidium. (n.d.). Siculicidium. In Wikipedia. Retrieved December 18, 2015, from http:// en.wikipedia.org/wiki/Siculicidium

Sinor, D. (1982). The Legendary Origin of the Türks. In E. V. Zygas \& P. Voorheis (Eds.), Folklorica: Festschrift for Felix J. Oinas (pp. 223-245). Bloomington: Research Institute for Inner Asian Studies. (Uralic and Altaic Series, 141)

Stewart, C. (1997). Anxiety, experience, and the limits of social constructionism in modern Greek dream narratives. American Ethnologist, 24(4), 877-894. http://dx.doi.org/ 10.1525/ae.1997.24.4.877

Szöllőssy, Á. (1991). A Napba öltözött asszony. Adalékok egy képtípus kialakulásának előzményeihez. Honismeret, 19(4), 17-20.

Tánczos, V. (1996). Keletnek megnyílt kapuja. Emlékképek a moldvai csángók szerkezet nélküli kultúrájáról. In V. Tánczos, Keletnek megnyílt kapuja (pp. 38-66). Kolozsvár: Korunk Baráti Társaság. Retrieved December 18, 2015, from http://www.korunk.org/ konyvek/letoltkonyvek/TanczosVilmos_Keletnek_megnyilt_kapuja_W.pdf 
Tánczos, V. (2010a). Napbaöltözött asszony ikonográfiája (A csíksomlyói Mária-kegyszobor). Retrieved December 18, 2015, from http://lexikon.adatbank.ro/tematikus/szocikk. php?id=62

Tánczos, V. (2010b). Csíksomlyó spiritualitásának néhány összetevője. Retrieved December 18, 2015, from: http://www.keresztenyszo.katolikhos.ro/archivum/2010/december/1.html

Tánczos, V. (2011). Csíksomlyó és a moldvai csángók (Részlet egy nagyobb tanulmányból. Kézirat). Retrieved December 18, 2015, from http://tanczosvilmos.files.wordpress. com/2011/09/csiksomlyo-es-a-moldvai-csangok.pdf

Tedlock, B. (1981). Quiché Maya dream interpretation. Ethos, 9(4), 313-330. http://dx.doi. org/10.1525/eth.1981.9.4.02a00050

Tedlock, B. (1992). The role of dreams and visionary narratives in Mayan cultural survival. Ethos, 20(4), 453-476. http://dx.doi.org/10.1525/eth.1992.20.4.02a00030

Uray-Kőhalmi, K. (2009). Csodaszarvas a tajgában. In Á. Molnár (Ed.), Csodaszarvas: őstörténet, vallás és néphagyomány (Vol. 3, pp. 19-26). Budapest: Molnár.

Vizkelety, A. (n.d.). Leuveni kódex-Ómagyar Mária-siralom. Retrieved December 18, 2015, from http://nyelvemlekek.oszk.hu/adatlap-dupla/leuveni_kodex_\%E2\%80\%93_ omagyar_mariasiralom 